\title{
DETEKSI FORMALIN PADA TOMAT DENGAN MENGGUNAKAN METODE LSI (LASER SPECKEL IMAGING)
}

\author{
Neneng Fitrya, Harmadi ${ }^{1}$, Sandra ${ }^{2}$ \\ ${ }^{1}$ Program Pascasarjana FMIPA Universitas Andalas \\ ${ }^{2}$ Departemen Teknik Pertanian, Fakultas Teknik Pertanian Universitas Andalas \\ Email : harmadi@fmipa.unand.ac.id
}

\begin{abstract}
ABSTRAK
Pendeteksian untuk mengetahui kandungan formalin pada buah tomat dapat dilakukan secara noninvasive dan non-destructive dengan metode LSI (Laser Speckle Imaging). Perubahan nilai kontras pola spekel dari buah tomat dapat digunakan untuk membedakan buah tomat yang berformalin dengan yang tidak berformalin. Pecintraan pola spekel dengan metode LSI mendeteksi perubahan intensitas laser spekel yang dihamburkan oleh sampel, dan dianalisis sebagai kontras spekel. Pola spekel dianalisis menggunakan software imageJ dan diperoleh karakterisasi histogram distribusi intensitas gray level. Penyinaran dilakukan terhadap buah tomat sebelum dan sesudah direndam larutan formalin dengan variasi konsentrasi $0,001 \%, 0,005 \%, 0,01 \%, 0,05 \%, 0,1 \%, 0,5 \%, 1 \%, 3 \%$, $4 \%, 5 \%, 6 \%, 8 \%, 10 \%$, dan variasi waktu perendaman yaitu selama 15 menit dan 30 menit. Secara umum korelasi kontras spekel dengan formalin pada tomat, menunjukkan bahwa formalin terdeteksi dengan perubahan kontras spekel pada buah tomat. Semakin tinggi konsentrasi formalin dan waktu perendaman nilai kontras spekel semakin kecil.
\end{abstract}

Kata kunci: formalin, kontras, LSI (Laser Speckle Imaging), pola spekel, tomat

\begin{abstract}
ABSTRAK
The detection to determine the formaldehyde content in tomatoes can be perfomed using noninvasive and and non-destructive by LSI (Laser Speckle Imaging ) method. Changes in contrast value of the speckle pattern of tomatoes can be used to distinguish the tomatoes with and without formaldehyde. The imaging of speckle pattern with LSI method detects changes in the intensity of the laser speckle that is scattered by the sample, and analyzed as speckle contrast. Speckle pattern was analyzed using imagej software and obtained characterization gray level intensity distribution histogram. Irradiation is carried out on tomato before and after the tomato soaked with various concentration of formaldehyde solution $0,001 \%, 0,005 \%, 0,01 \%, 0,05 \%, 0,1 \%, 0,5 \%, 1 \%, 3 \%$, $4 \%, 5 \%, 6 \%, 8 \%, 10 \%$, and the variation immersion time for 15 minutes and 30 minutes. In general, the speckle contrast correlation with formaldehyde in tomatoes, showed that formaldehyde was detected by speckle contrast changes in tomatoes. The higher concertration of formaldehyde and immersion time, speckle contrast value will get smaller.
\end{abstract}

Keyword: contrast, formaldehyde, LSI (Laser Speckle Imaging), spekel pattern, tomato

\section{PENDAHULUAN}

Buah tomat (Lycopersicum esculentum Mill) merupakan salah satu komoditas holtikultura yang multiguna. Buah tomat mudah mengalami kerusakan jika tidak disimpan pada kondisi yang baik. Besarnya kerusakan buah tomat setelah panen berkisar antara 20\% sampai dengan $50 \%$ [1].

Mutu pascapanen hasil hortikultura seperti tomat umumnya tidak dapat diperbaiki, tetapi dapat dipertahankan dengan pengawetan. Tomat yang mengandung formalin banyak ditemukan di pasaran dengan alasan agar kelihatan lebih segar dan dapat bertahan lama. 
Pendeteksian zat formalin pada buah cukup sulit dilakukan jika hanya dilihat dari segi fisiknya, sehingga diperlukan pengujian lebih lanjut dengan menggunakan teknik imaging non-invasive dan non-destructive yang digunakan untuk sistem biologi. Salah satu teknik imaging non-destructive yang digunakan adalah metode LSI (Laser Speckle Imaging) untuk mendeteksi sinyal optik dari jaringan biologi. Fenomena spekel yang dihasilkan dari pencahayaan laser terhadap bahan aktif, seperti jaringan biologi disebut dinamika spekel atau biospekel. Biospekel membawa informasi tentang aktivitas biologis dan fisiologis sampel biologis [2]. Pada metode ini, material disinari berkas koheren dari laser, terjadi hamburan dan membentuk pola spekel pada bidang pengamatan [3].

Pengujian pada buah-buahan menggunakan sistem laser spekel dapat digunakan untuk melihat kerusakan, proses penuaan, sifat mekanis dan struktur permukaan buah. Pengembangan metode LSI ini dapat diaplikasikan pada buah-buahan untuk deteksi formalin dengan prinsip hamburan cahaya laser yang ditembakkan pada buah sehingga didapatkan pola spekel dari buah tersebut. Sistem LSI terdiri dari tiga komponen utama yaitu laser sebagai sumber cahaya, sampel dan sebuah detektor cahaya. Keunggulan LSI adalah minim efek samping (non destructive, non invasive, non ionisasi) [4], memiliki pencitraan penuh, akuisisi data langsung, akurat, kuantitatif dan biaya rendah [5].

\section{METODE}

Pengujian pada buah-buahan menggunakan sistem laser spekel untuk melihat formalin pada buah dengan prinsip hamburan cahaya. Ketika berkas koheren dari laser dikenakan pada permukaan bahan, maka terbentuklah pola interferensi yang khas dalam bentuk suatu granular (butiran) bernama spekel [6]. Pola gelap terang dari spekel terjadi karena frekuensi yang berbeda. Deskripsi tentang statistik distribusi intensitas yang dihasilkan oleh spekel, diasumsikan bahwa medan yang koheren dengan panjang gelombang $\lambda$ menerangi permukaan suatu bahan yang berarti panjang gelombang yang dipilih memiliki ukuran yang lebih kecil dari bahan yang digunakan. Kekasaran suatu bahan akan menyebabkan distribusi intensitas dan fase yang acak. Hal ini berhubungan dengan nilai mean. Bidang cahaya dalam suatu ruang pada titik tertentu $\mathrm{P}(\mathrm{x}, \mathrm{y}, \mathrm{z})$ dalam pola spekel haruslah merupakan jumlah dari total hamburan $\mathrm{N}$, yang mewakili distribusi dari semua titik pada permukaan yang terhambur. Jika diberi pencahayaan dari cahaya monokromatik maka cahaya terhambur terhadap bidang $\mathrm{P}$ yang dihasilkan oleh setiap elemen permukaan dijabarkan [3], diberikan oleh Persamaan 2.1:

$$
(P)=\left|u_{j}\right| e^{i \phi_{j}}=\left|u_{j}\right| e^{i k r_{j}}
$$

adalah jarak (variasi acak) dari elemen hamburan permukaan ke j pada titik P. Amplitudo kompleks medan hamburan di titik P dituliskan pada Persamaan 2.2 sebagai:

$$
U(P)=\frac{1}{\sqrt{N}} \sum_{j=1}^{N} u_{j}(P)=\frac{1}{\sqrt{N}} \sum_{j=1}^{N}\left|u_{j}\right| e^{i \phi_{j}}=\frac{1}{\sqrt{N}} \sum_{j=1}^{N}\left|u_{j}\right| e^{i k r_{j}}
$$

Penjumlahan dalam Persamaan 2.2 merupakan cara acak dalam bidang kompleks, dengan fasa acak $\phi_{j}=k r_{j}$.

Dengan mengasumsikan amplitudo $u_{j}$ dan fase $\phi_{j}$ pada setiap komponen medan secara statistik independent (bebas/ tidak bergantung) satu sama lain, dan tidak bergantung dari amplitudo dan fase komponen medan lainnya. Fase $\phi_{j}$ didistribusikan secara menyeluruh pada interval $(-\pi, \pi)$, yang berarti bahwa permukaan kasar dibandingkan dengan panjang gelombang, dan jumlah hamburan total $\mathrm{N}$ sangat besar, sehingga menjamin validitas dari teotema limit sentral. Goodman telah menunjukkan bahwa bagian real dan 
imajiner dari medan resultan adalah asimtotik Gaussian [7]. Fungsi densitas probabilitas bersama diberikan oleh persamaan 2.3.

$$
P_{r_{i} i}\left(U^{(x)}{ }_{y} U^{(i)}\right)=\frac{1}{2 \pi \sigma^{2}} \exp \left[\frac{\left(U^{(x)}\right)^{2}+\left(U^{(t)}\right)^{2}}{2 \sigma^{2}}\right]
$$

Dengan nilai Circular Gaussian, adalah:

$$
\sigma^{2}=\lim _{N \rightarrow \infty} \sum_{j=1}^{W} \frac{\left(\mathbb{u}_{j} \mid j^{2}\right.}{2}
$$

Dari Persamaan 2.3, dan dengan menghitung intensitas $I$ dan fase $\Phi$ medan resultan pada bagian real dan imajiner medan mengacu pada Persamaan 2.5.

$$
\begin{aligned}
& U^{(x)}=\sqrt{I} \cos \phi \\
& U^{(i)}=\sqrt{I} \sin \phi
\end{aligned}
$$

Selanjutnya probabilitas intensitas $p(I)$ dan probabilitas fase $p(\Phi)$, diberikan oleh Persamaan 2.6 dan 2.7.

$$
\begin{aligned}
& p(I)=\frac{1}{\sqrt{I}} e^{-\frac{l}{4}} \text { untuk } I \geq 0 \\
& p(\Phi)=\frac{1}{2 \pi} \quad \text { untuk }-\pi \leq \Phi \leq \pi
\end{aligned}
$$

Secara berturut-turut di dalam Persamaan 2.6, $\langle I\rangle$ adalah nilai rata-rata intensitas pada diagram spekel. Menurut dua persamaan terakhir, distribusi intensitas mengikuti hukum eksponensial negatif dimana fase terdistribusi secara merata dalam interval $(-\pi, \pi)$. Distribusi kejadian intensitas didefinisikan pada persamaan 2.8.

$$
\langle I\rangle=n !\left(2 \sigma^{2}\right)^{n}=n !\langle I\rangle^{n}
$$

khusus pada orde kedua dinyatakan dalam persamaan 2.9.

$$
\begin{aligned}
& \left\langle I^{2}\right\rangle=2\langle I\rangle^{2} \\
& \sigma_{1}^{2}=\left\langle I^{2}\right\rangle-\langle I\rangle^{2}=\left\langle I^{2}\right\rangle
\end{aligned}
$$

Persamaan ini menunjukkan bahwa standar deviasi dari pola spekel terpolarisasi sama dengan nilai rata-rata intensitas. Dengan menghitung pola modulasi spekel yang dinyatakan sebagai kontras, didefinisikan pada persamaan 2.10.

$$
C=\frac{q_{l}}{Q d v}
$$

Kontras merupakan gabungan dari pola spekel yang menjadi kesatuan. Berdasarkan persamaan di atas, $\langle I\rangle$ adalah nilai rata-rata intensitas, $\sigma_{I}$ adalah standar deviasi dari intensitas, dan $C$ adalah kontras.

Spekel adalah efek stokastik yang berhubungan dengan variabel acak yang didefinisikan pada ruang probabilitas, sehingga hanya dapat digambarkan secara statistik. Terdapat beberapa pendekatan statistik diantaranya adalah evaluasi statistik orde pertama dan kedua. Orde pertama adalah gambaran statistik dari intensitas dan kontras spekel pada suatu pola dalam citra tunggal. Pendekatan ini menunjukkan standar deviasi $(\sigma)$ intensitas adalah nilai rata-rata intensitas $\langle I\rangle$ pola spekel. Nilai kontras dapat dinyatakan sebagai $C=\frac{\sigma_{l}}{(b)}$ dengan satuan a.u (arbitrary unit), dan ketika rasio bernilai 1, maka pola disebut memiliki konstras maksimum. 
Sistem pencitraan optis ini digunakan untuk mendeteksi formalin pada buah tomat, dengan menggunakan perangkat sistem LSI yang terdiri sumber laser continous wave $(\mathrm{CW})$ dari laser He-Ne yang memiliki intensitas lebih rendah dari cahaya tampak. Sumber cahaya laser He-Ne dengan $\lambda=632,8 \mathrm{~nm}$ berdaya keluaran $0,8 \mathrm{~mW}$ diaplikasikan pada material bersifat tidak merusak (nonperturbing) atau tidak memberikan efek nyata terhadap sampel. Buah tomat disinari laser untuk mendapatkan pola spekel. Dalam pendeteksian formalin pada buah tomat, diamati perubahan nilai kontras dari pola spekel sebelum dan sesudah diberi perlakuan perendaman dengan larutan formalin, karena itu dilakukan penyinaran pada buah sebelum dan sesudah direndam formalin dengan variasi konsentrasi 2\%, 3\%, 4\%, dan 5\% selama 15 menit dan 30 menit. Kerangka konseptual penelitian ditunjukkan dengan diagram alir pada Gambar 1.

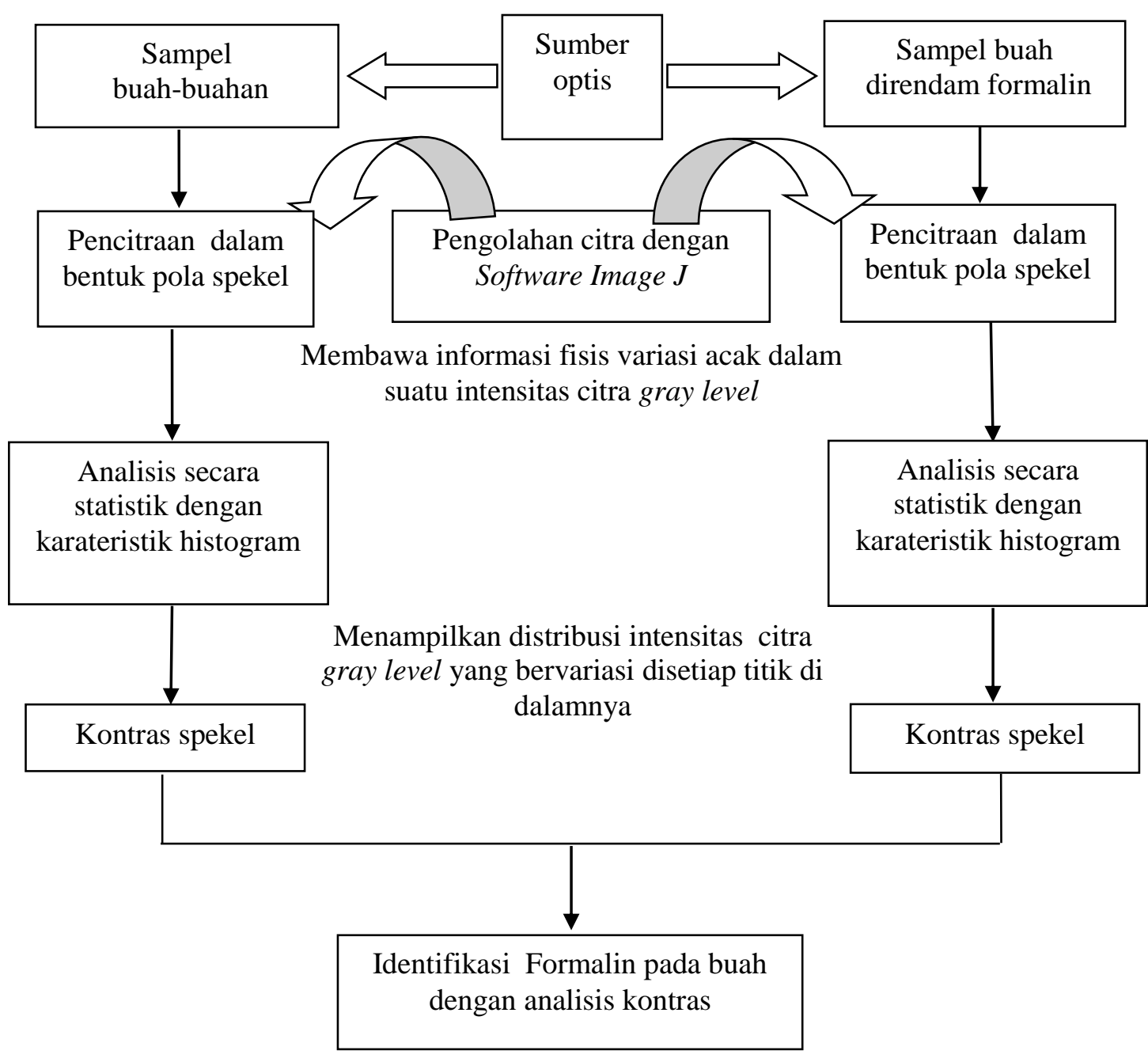

Gambar 1. Kerangka konseptual penelitian

Citra spekel dapat diperoleh dari cahaya hamburan balik, ketika berkas laser mencapai permukaan material akan dipantulkan yang kemudian ditangkap oleh detektor dan dipindahkan ke sistem pengolahan. Detektor yang digunakan adalah kamera CCD karena bersifat sensitif terhadap cahaya, keluaran A4tech model PK-836F dengan $30 \mathrm{fps}$. Sistem 
komputer dilengkapi dengan software Ulead VideoStudio-7 sebagai komponen display visual untuk merekam dan menampilkan pola spekel, sehingga diperoleh nilai kontras spekel. Susunan rancangan spekel dapat dilihat pada Gambar 2.

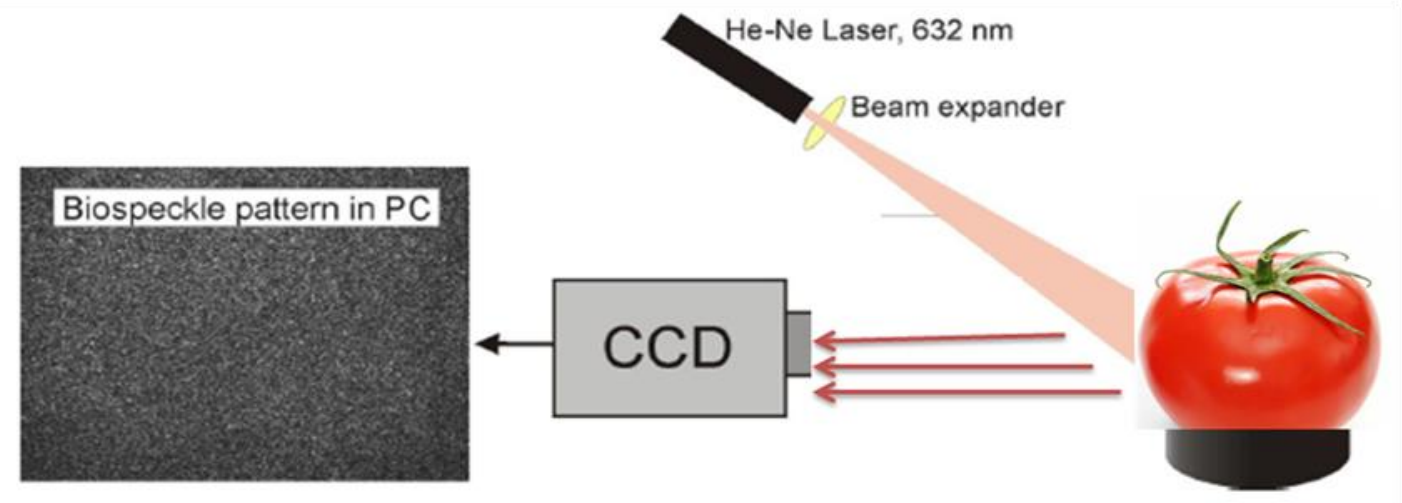

Gambar 2. Susunan rancangan spekel

Pola spekel diolah dengan menggunakan software pengolah citra ImageJ, digunakan untuk mengolah citra pola spekel bahan uji melalui karakterisasi histogram intensitas gray level (tingkat keabu-abuan) dari citra, sehingga dapat ditentukan kontras spekel dari sampel buah tomat tersebut. Selain itu, dilakukan juga pengamatan dengan mikroskop optik stereo Carton SPZT50 untuk melihat struktur permukaan tomat sebelum dan setelah direndam formalin. Pengamatan dilakukan dengan perbesaran 50 kali.

\section{HASIL DAN PEMBAHASAN}

Penelitian yang telah dilakukan menghasilkan bentuk pola spekel dari pencitraan spekel tomat. Pola spekel yang dihasilkan dalam bentuk citra dengan ukuran 640x480 piksel. Hasil pengamatan pola spekel sampel yang telah diperoleh, diproses menggunakan software ImageJ untuk mendapatkan karakterisasi histogram distribusi intensitas tingkat keabuan pada kondisi sebelum dan setelah direndam formalin. Nilai kontras spekel ini dapat digunakan untuk mengamati buah yang berformalin dengan tidak berformalin.

Histogram menggambarkan penyebaran nilai intensitas dalam satu piksel dari suatu citra (gambar). Nilai intensitas (kontras) suatu gambar bernilai 0- 255, nilai 0 menyatakan nilai palin gelap (hitam) dan 255 menyatakan nilai paling terang (putih). Bila digambarkan pada koordinat kartesian sumbu X (absis) menunjukkan tingkat warna dan sumbu Y (ordinat) menunjukkan frekuensi kemunculan. Hasil pengamatan pola spekel yang dipaparkan pada Gambar 3 (dalam skala keabu-abuan).

Analisis secara statistik menggunakan karakteristik histogram menampilkan distribusi intensitas tingkat keabuan citra yang bervariasi di setiap titik dalam citra, sehingga dapat ditentukan nilai rata-rata intensitas $\langle I\rangle$ dan simpangan baku intensitas $\sigma_{I}$ yang merupakan ukuran variasi simpangan intensitas dari keseluruhan citra tersebut. Berdasarkan perolehan nilai rata-rata intensitas dan simpangan baku intensitas keseluruhan citra, maka dapat ditentukan kuantitas citra dalam bentuk kontras spekel C, yang merupakan rasio antara simpangan baku intensitas $\sigma_{I}$ dengan nilai rata-rata intensitas $\langle I\rangle$. Standar deviasi menyatakan bahwa simpangan intensitas pada keseluruhan gambar. Semakin besar nilai standar deviasi maka semakin ragam intensitas yang dibentuk pada gambar. Pada histogram terdapat puncak yang menyatakan puncak tertinggi merupakan nilai intensitas yang paling banyak intensitas terbentuk pada keseluruhan pikselnya. 


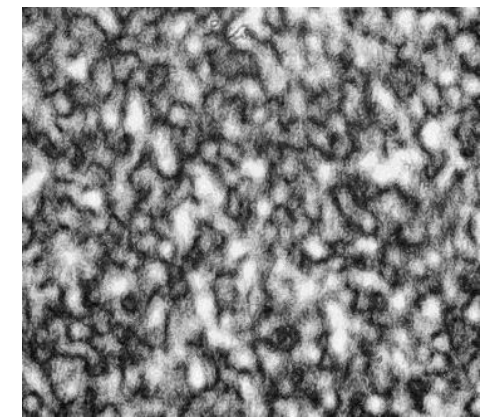

(a)

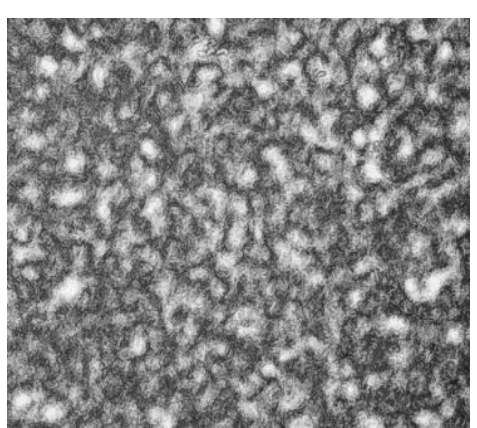

(b)

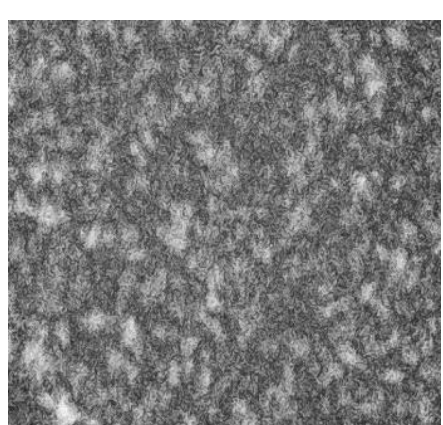

(c)

Gambar 3. Perbandingan pola spekel terhadap variasi konsentrasi

(a). Pola spekel buah tomat sebelum direndam formalin

(b). Pola spekel buah tomat setelah direndam formalin 0,001\%

(c). Pola spekel buah tomat setelah direndam formalin $7 \%$

Nilai kontras spekel buah tomat dikelompokkan berdasarkan variasi konsentrasi formalin dan variasi waktu perendaman, sebelumnya diamati nilai kontras spekel buah tomat yang belum direndam formalin, nilai kontras spekel tomat sebelum direndam formalin dipaparkan pada Gambar 4 dan nilai kontras buah tomat setelah diformalin dengan variasi konsentrasi dipaparkan pada Gambar 5. Sedangkan pada Gambar 6 diperlihatkan pengaruh variasi waktu perendaman terhadap perubahan nilai kontras.

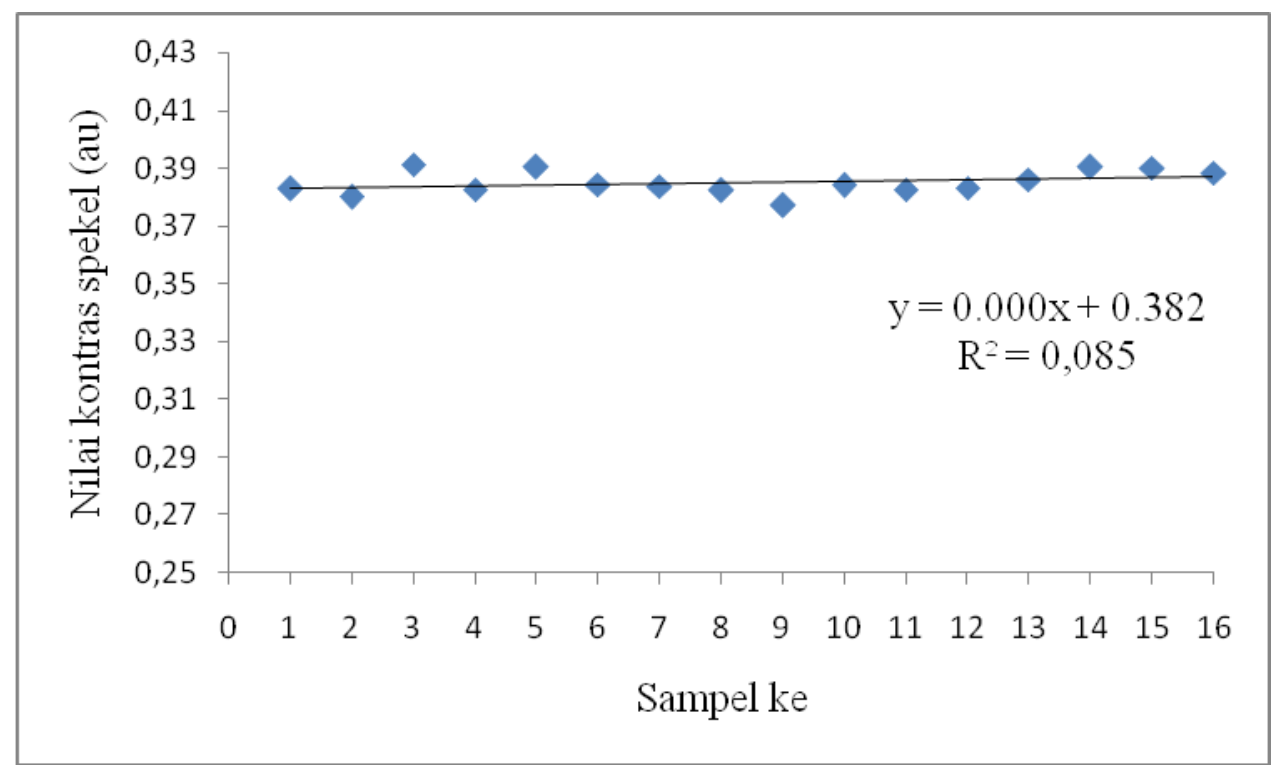

Gambar 4. Nilai kontras spekel tomat sebelum direndam formalin 


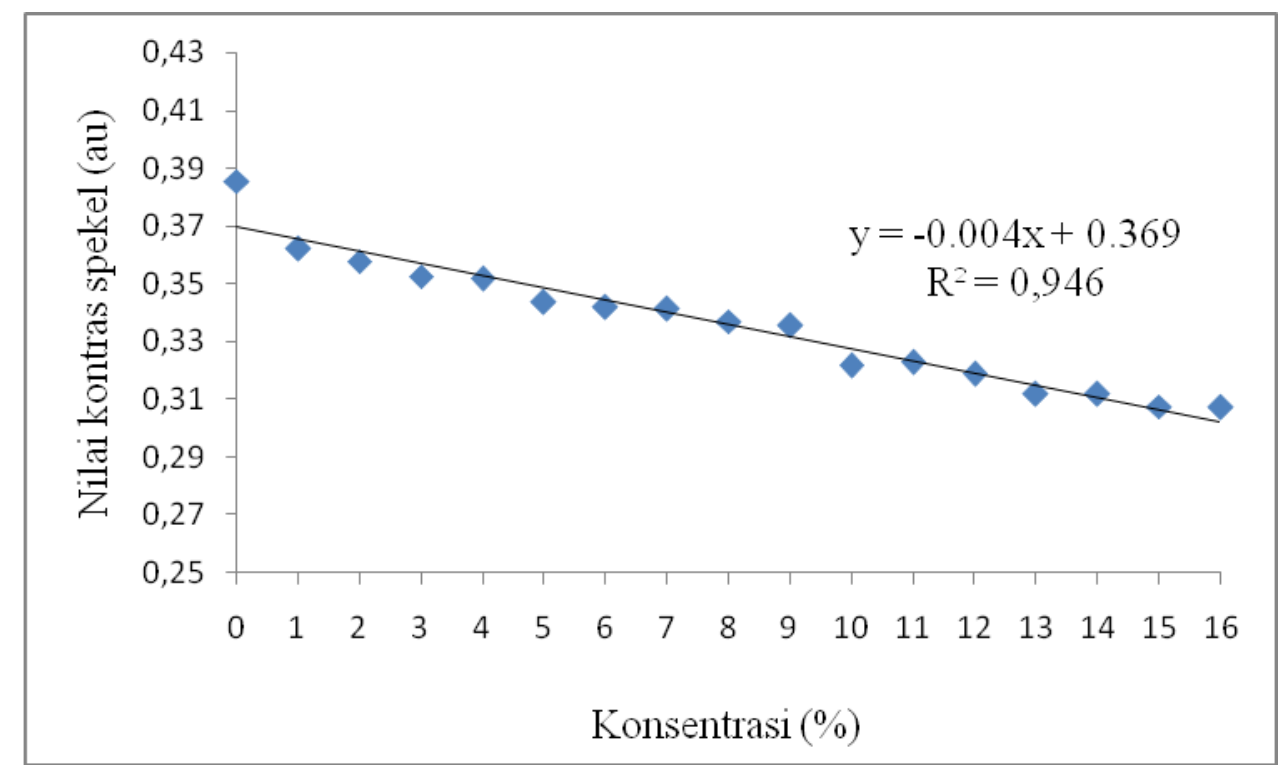

Gambar 5. Nilai kontras buah tomat setelah diformalin dengan variasi konsentrasi

Secara keseluruhan diperoleh perubahan nilai kuantitas citra pola spekel dalam bentuk kontras spekel sampel buah tomat pada kondisi sebelum dan setelah direndam formalin pada konsentrasi tertentu dengan variasi waktu perendaman. Secara umum pada semua sampel tomat terjadi perubahan nilai kontras spekel sebelum dan setelah direndam dengan formalin, dimana nilai kontras spekel setelah direndam formalin mengalami penurunan dibandingkan dengan nilai kontras sebelum direndam formalin.

Penurunan nilai kontras secara keseluruhan dapat dilihat pada Gambar 7. Secara keseluruhan menunjukkan perubahan nilai kontras spekel terhadap variasi konsentrasi dan waktu perendaman. Setiap perubahan konsentrasi memperlihatkan perubahan nilai kontras dari pola spekel tomat yang dihasilkan dari proses penembakan dengan laser dan dengan penambahan waktu perendaman nilai kontras cenderung semakin turun untuk setiap variasi konsentrasi. Nilai kontras dapat digunakan untuk membedakan tomat yang mengandung formalin dan tanpa formalin, sesuai dengan hasil pengamatan dimana nilai kontras mengalami perubahan akibat adanya perlakuan dengan formalin.

Secara umum pengamatan kontras spekel jika dikaitkan dengan formalin pada tomat, menunjukkan bahwa formalin terdeteksi dengan perubahan kontras spekel pada buah tomat tersebut. Tomat yang mengandung formalin memiliki nilai kontras yang lebih kecil dibandingkan dengan tomat tanpa formalin, karena adanya lapisan baru yang terbentuk setelah direndam formalin. Mekanisme formalin sebagai pengawet adalah dengan membunuh bakteri dengan membuat jaringan dalam bakteri dehidrasi (kekurangan air), sehingga sel bakteri akan kering dan membentuk lapisan baru di permukaan, lapisan baru ini yang melindungi lapisan di bawahnya, supaya tahan terhadap serangan bakteri lain. Semakin tebal lapisan, nilai kontras akan semakin kecil karena cahaya yang terhambur dari penyinaran laser juga semakin kecil akibat lapisan tersebut. 


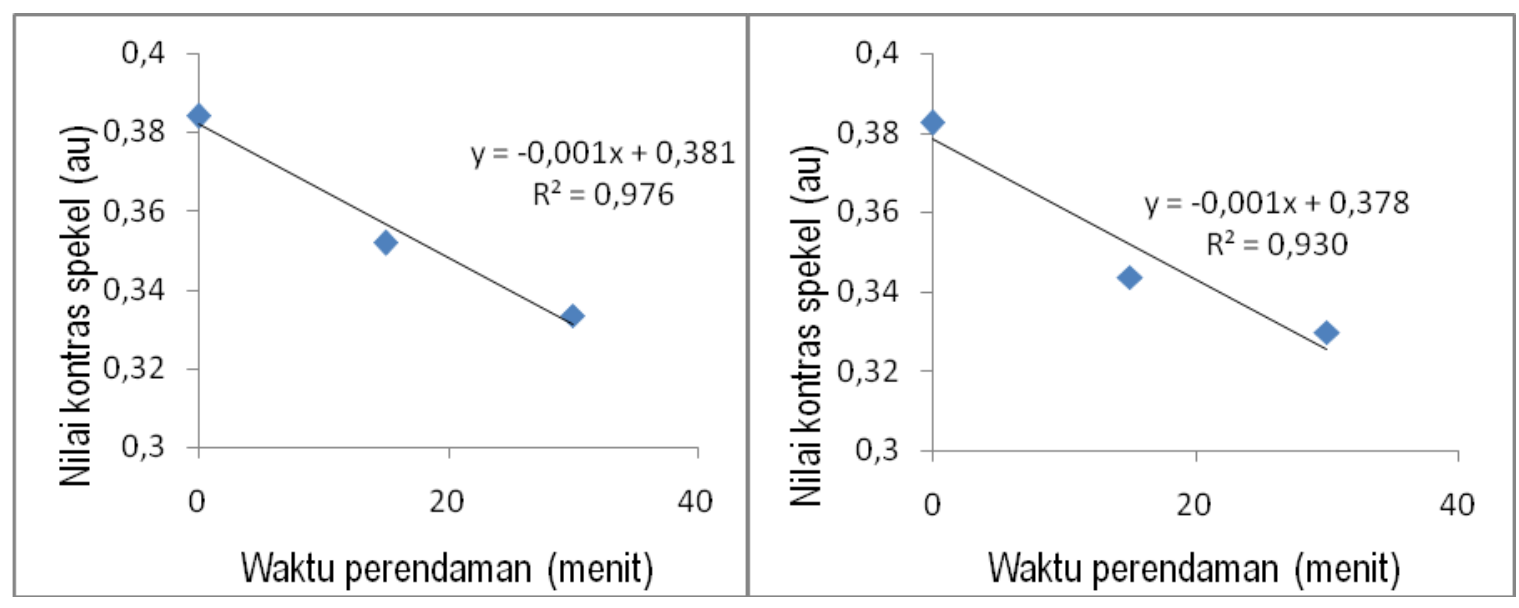

(a)

(b)

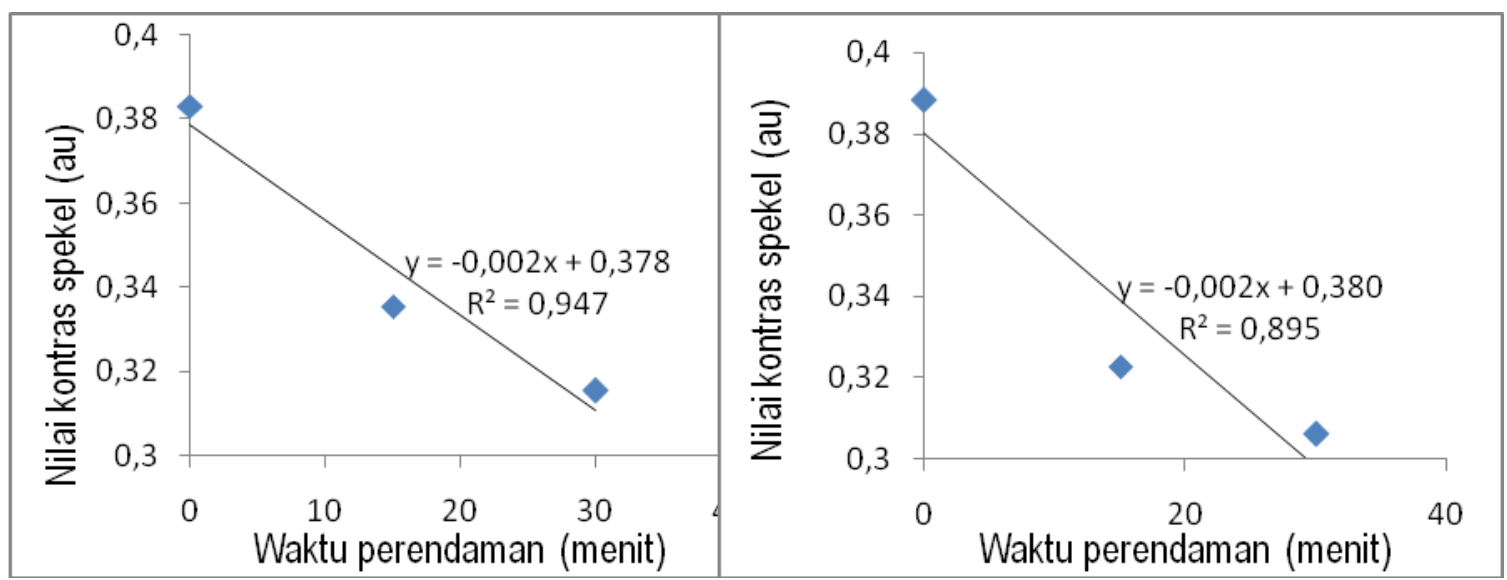

(c)

(d)

Gambar 6. Perubahan nilai kontras terhadap variasi waktu perendaman

(a). Perubahan nilai kontras terhadap waktu perendaman pada konsentrasi formalin $2 \%$

(b). Perubahan nilai kontras terhadap waktu perendaman pada konsentrasi formalin 3\%

(c). Perubahan nilai kontras terhadap waktu perendaman pada konsentrasi formalin $4 \%$

(d). Perubahan nilai kontras terhadap waktu perendaman pada konsentrasi formalin $5 \%$ 


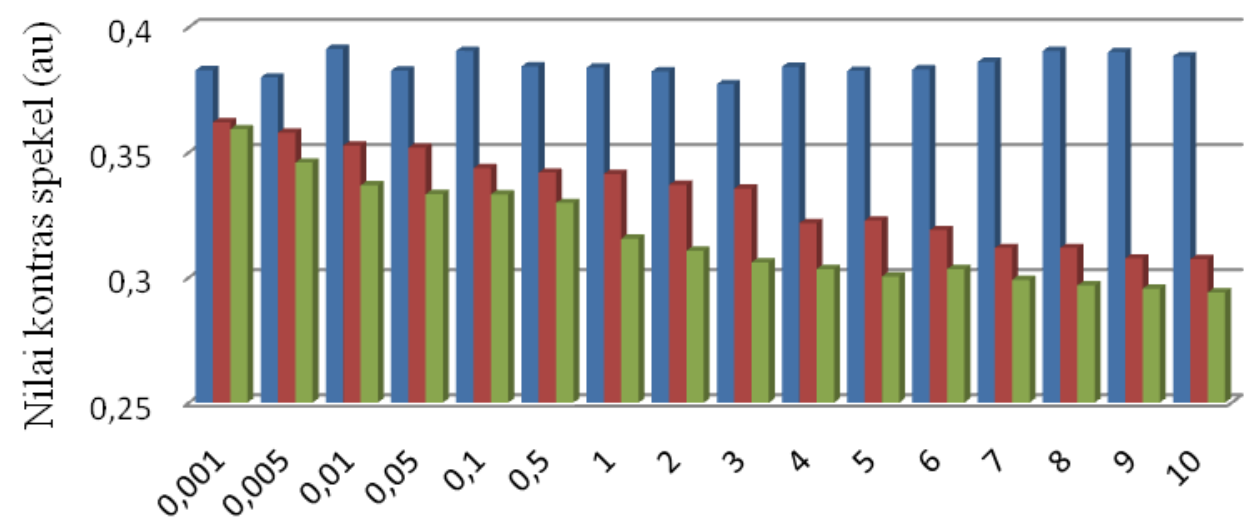

Konsentrasi (\%)

घebelum direndam formalin a direndam 15 menit $\quad$ direndam 30 menit

Gambar 7. Perubahan nilai kontras terhadap variasi konsentrasi dan waktu perendaman

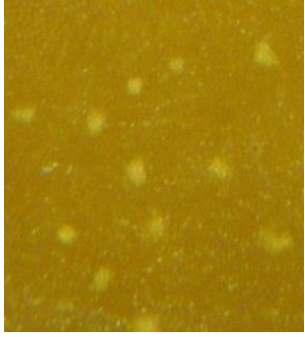

Tanpa fomalin
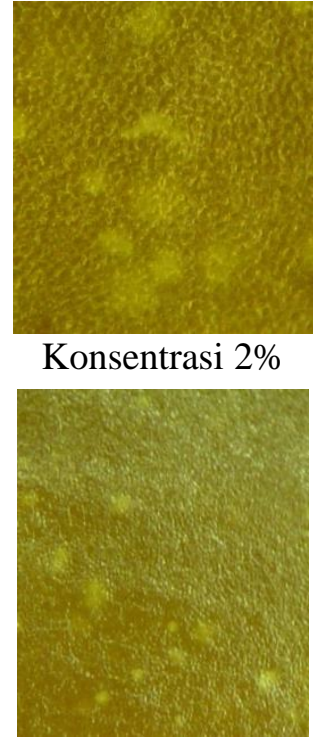

Konsentrasi $3 \%$
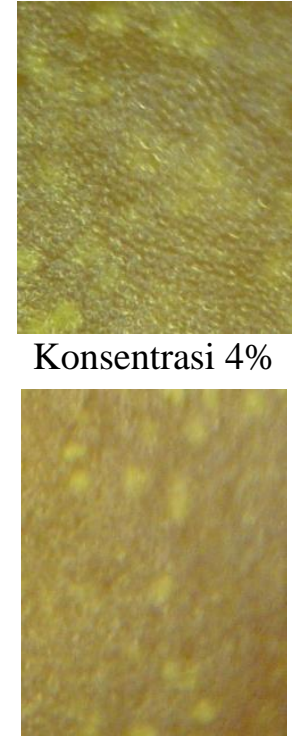

Konsentrasi 5\%

Gambar 8. Permukaan tomat dilihat dengan mikroskop optik

Lapisan pada permukaan yang terbentuk setelah direndam formalin diperlihatkan pada dilihat pada Gambar 8, lapisan ini dilihat menggunakan mikroskop optik stereo carton SPZT50 dengan perbesaran 50 kali. Jika penambahan konsentrasi dan lama perendaman dihubungkan dengan nilai kontras spekel maka dapat disimpulkan bahwa dengan bertambahnya konsentrasi dan lama perendaman berbanding terbalik dengan nilai kontras spekel yang dihasilkan.

\section{KESIMPULAN}

Formalin pada tomat dapat dideteksi menggunakan sistem LSI dengan analisa perubahan nilai kontras dari pola spekel tomat. Nilai kontras buah berformalin lebih kecil dibanding dengan nilai kontras tanpa formalin. Konsentrasi dan lama perendaman berbanding 
terbalik dengan nilai kontras spekel yang dihasilkan. Semakin tinggi konsentrasi dan waktu perendaman, maka lapisan yang terbentuk semakin tebal sehingga nilai kontras semakin menurun, karena cahaya yang terhambur dari penyinaran laser juga semakin kecil akibat lapisan tersebut.

\section{DAFTAR PUSTAKA}

1. Kartosapoetro, AG., 1994, Tehnologi Penanganan Pasca Panen, Rineka Cipta, Jakarta.

2. Rabal H. J., and Braga R. A.,2009., Dynamic Laser Speckel and Applications. Optical science and engineering: 139, Taylor \& Francis Group, LLC.

3. Ansari, Z.M dan Nirala, A.K., 2012, Activity Assessment of Fruits Using the Methods of Inertia Moment and Absolute Value of the Differences, Biomedical Optics Laboratory, Department of Applied Physics, Indian School of Mines Dhanbad, India.

4. Apsari, R., 2009, Sistem Fuzzy Berbasis Laser Speckle Imaging untuk Deteksi Kualitas Enamel Gigi Akibat Paparan Laser ND:YAG, Disertasi, PPs Universitas Airlangga, Surabaya

5. Harmadi, 2011, Aplikasi Pola Spekel Akusto-Optik untuk Pendeteksian Vibrasi Akustik pada Dental Plaque Biofilm, Disertasi, PPs Universitas Airlangga, Surabaya

6. Goodman J.W., Speckle Phenomena in Optic; Theory and Application, (Robert and Co., Englewood, Colorado, 2007).

7. Goodmann, J.W., 1976, Some Fundamental Properties of Speckel. J. Opt. Soc. Am, 66,1145 . 